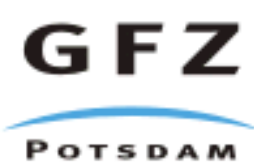

Originally published as:

Lorenzo-Martin, F., Roth, F., Wang, R. J. (2006): Elastic and inelastic triggering of earthquakes in the North Anatolian Fault zone. - Tectonophysics, 424, 3-4, 271-289

DOI: $10.1016 /$ j.tecto.2006.03.046 


\section{Elastic and inelastic triggering of earthquakes in the North Anatolian Fault zone}

Francisco Lorenzo-Martín ${ }^{1, *}$, Frank Roth², Rongjiang Wang ${ }^{2}$

1 Institute of Geology, Mineralogy and Geophysics, Ruhr University Bochum, D-44780 Bochum, Germany.

2 GeoForschungsZentrum Potsdam (GFZ), Telegrafenberg, D-14467 Potsdam, Germany.

* Corresponding author:

GeoForschungsZentrum Potsdam (GFZ)

Telegrafenberg

D-14467 Potsdam

Germany

Tel: +49331288 1285

Fax: +49 3312881204

E-mail address: lorenzo@gfz-potsdam.de (F. Lorenzo). 


\section{Abstract}

Deformation models used for explaining the triggering mechanism often assume pure elastic behaviour for the crust and upper mantle. In reality however, the mantle and possibly the lower crust behave viscoelastically, particularly at long-term scale. Consequently, the stress field of an earthquake is in general time dependent. In addition, if the elastic stress increase were enough to trigger a later earthquake, this triggered event should occur instantaneously and not many years later. Hence, it is adequate to include inelastic behaviour when analysing stress transfer and earthquake interaction.

In this work, we analyse a sequence of 10 magnitude $\mathrm{M}_{\mathrm{s}}>6.5$ events along the North Anatolian Fault between 1939 and 1999 to study the evolution of the Coulomb stress field. We investigate the triggering of events in the series by stress transfer, taking viscoelastic relaxation into account. We evaluate the contribution of elastic stress changes, of post-seismic viscoelastic relaxation in the lower crust and mantle, and of steady tectonic loading to the total Coulomb stress field. We analyse the evolution of stress in the region under study, as well as on the rupture surfaces of the considered events and their epicentres. We study the state of the Coulomb stress field before the 1999 Izmit and Düzce earthquakes, as well as in the Marmara Sea region.

In general, the Coulomb stress failure criterion offers a plausible explanation for the timing and location of the events in this area and for this sequence of events. However, we show that using a purely elastic model disregards an important part of the actual stress increase/decrease. In several cases, post-seismic relaxation effects are important and greater in magnitude than the stress changes due to steady tectonic loading. Consequently, viscoelastic relaxation should be considered in any study dealing with Coulomb stress changes. 
According to our study, and assuming that an important part of the rupture surface must be stressed for an earthquake to occur, the most likely value for the viscosity of the lower crust or mantle in this region is $5 \cdot 10^{17}-10^{18} \mathrm{~Pa} \cdot \mathrm{s}$. Our results also suggest that other time-dependent processes apart from viscoelastic relaxation might have been involved in the triggering of the 1999 Düzce event. Finally, we argue that the Marmara Sea region is currently being loaded with positive Coulomb stresses at a much faster rate than would arise exclusively due to steady tectonic loading on the North Anatolian Fault.

Keywords: Coulomb stress, triggering, North Anatolian Fault, dislocation theory, rheology, viscosity 


\section{Introduction}

The North Anatolian Fault zone (NAF) is a mainly pure dextral 1500 km long fault zone running along the north of Turkey (Fig. 1). During the last century, several strong earthquakes have taken place along the NAF. These events or subsets of them have been the subject of numerous studies (Mogi, 1968; Toksöz et al., 1979; Purcaru and Berckhemer, 1982; Roth, 1988; Stein et al., 1997). There are several reasons for the interest: first, the events provide an unequalled possibility to analyse how the occurrence of an earthquake may trigger additional shocks. Second, the number of field investigations provides a valuable and still increasing amount of information. Third, recent events appear to be propagating westwards, with the $\mathrm{M}_{\mathrm{w}}=7.4$ Izmit and the $\mathrm{M}_{\mathrm{w}}=7.1$ Düzce earthquakes in 1999 as the most recent and westernmost events. If this sense of propagation continues, a strong shock west of the Izmit and Düzce ruptures can be expected (Parsons et al., 2000). This region would be the Marmara Sea, just south of Istanbul, a mega-city with 12 million inhabitants. A strong earthquake in this region would therefore have catastrophic consequences, both in loss of life and monetary costs.

The triggering of earthquakes by stress transfer has been analysed by numerous authors (Healy et al., 1968; Raleigh et al., 1972; Harris, 1998 and references therein; Belardinelli et al., 1999; Belardinelli et al., 2003; Hardebeck, 2004). Deformation models often assume a purely elastic behaviour for the crust and upper mantle, and therefore the crust instantaneously responds to the motion on the rupture. When using the elastic approach, any time dependence of the deformation might be attributed to time-dependent fault slip (Kasahara, 1975; Linde and Silver, 1989; Barrientos et al., 1992). Several studies have shown good correlation between calculated positive elastic stress change and the location of aftershocks (Reasenberg and Simpson, 1992; Stein et al., 1992; King et al., 1994; Toda et al., 
1998; Deng et al., 1999), as well as the triggering of moderate to large earthquakes (King et al., 1994; Stein et al., 1994; Harris et al., 1995; Stein et al., 1997; Stein, 1999).

However, in the real Earth, the mantle and possibly the lower crust behave as an inelastic body; that is, any imposed stress will relax with time. The crust will first deform as an elastic body but later on the deformation will continue because of stress relaxation (Roth, 1983; Thatcher and Rundle, 1984). Since inelastic stress relaxation also leads to changes in the stress distribution, it is necesary to include inelastic behaviour when analysing stress transfer and earthquake interaction. Also, an important limitation of the elastic/co-seismic stress change approach is that it cannot explain time delays in the triggering process. Post-seismic stress changes due to viscous relaxation in the lower crust or upper mantle have also been successfully used to explain aftershock distribution and the triggering of later events (Deng et al., 1999; Freed and Lin, 2001; Zeng, 2001; Pollitz and Sacks, 2002). However, only pairs of events have been considered so far to analyse whether, and how, the Coulomb stress is increased by post-seismic relaxation.

In the present study, we investigated a sequence of 10 magnitude $M_{s}>6.5$ earthquakes (Table 1 and Figure 2) that have occurred on this fault since 1939. The geographical region considered brackets the Marmara Sea in the west to east of Erzincan. The last strong events before 1939 in this region took place in the $18^{\text {th }}$ century (Ambraseys and Finkel, 1995). We can assume therefore that the 1939 event was the first in a new seismic cycle, and that the stress field in the region has been homogenized by steady tectonic loading. We studied the changes in the Coulomb stress field from the beginning of the sequence to the present day. We considered the instantaneous response to the events, the effects of stress change due to tectonic loading from steady slip beneath the NAF, and the effect of viscoelastic relaxation in the lower crust and upper mantle. We evaluated the importance of these three processes on the total stress field. We analysed the time evolution of the Coulomb stress at the epicentres of the 
shocks, as well as the situation on the rupture surfaces immediately before the earthquakes, under different assumptions. We also considered the current situation in the Marmara Sea and extrapolated it to the year 2010 to evaluate the rate at which viscoelastic relaxation is increasing the stresses in the region, information that may be useful for seismic-hazard assessment in the region.

\section{Tectonic setting}

The tectonic setting of the studied region is dominated by the collision of the Arabian and African plates against the Eurasian and Anatolian ones (Fig. 1). The Arabian and African plates move approximately northward against the relatively stable Eurasian plate, causing the Anatolian block to move westwards from the East Anatolian Convergence Zone onto the oceanic lithosphere of the Eastern Mediterranean Sea (Sengör et al., 1985). This movement changes its direction to southwest in West Anatolia and the Aegean Sea, so that the large scale result is a counter-clockwise rotation of the Anatolian Plate (McKenzie, 1972; Jackson and McKenzie, 1988; McClusky et al., 2000). This relative westward movement of the Anatolian Plate generates strike slip on both the NAF and the East Anatolian Fault zone (EAF). Along most of the NAF, the right-lateral slip has a rate of $24 \pm 1 \mathrm{~mm} / \mathrm{a}$ (McClusky et al., 2000; Flerit et al., 2004).

The NAF splits into three different branches at its westernmost part. About $80 \%$ of the total slip accommodates on the northern branch and the remaining $20 \%$ is distributed between the other two (Flerit et al., 2003). The northern branch crosses the Marmara Sea, linking the Izmit segment to the East with the Ganos fault to the West (Le Pichon et al., 2001; Gokasan et al., 2003; Armijo et al., 2005). The NAF in the Marmara Sea consists of two main parts: a 
western one, about $120 \mathrm{~km}$ long and striking $\mathrm{N} 265^{\circ} \mathrm{E}$, and a $50 \mathrm{~km}$ long eastern segment, striking $\mathrm{N} 280^{\circ} \mathrm{E}$. These two segments were the probable location of several strong and damaging historical earthquakes in 1754 and 1766 (Ambraseys and Finkel, 1991). The Marmara Sea region has also been identified as a seismic gap (Hubert-Ferrari et al., 2000).

\section{Method}

During the last decade, Coulomb stress calculations have become a popular and accepted tool to analyse the conditions under which earthquakes occur (King et al., 1994; Stein et al., 1997; Zeng, 2001; Muller et al., 2003; Lin and Stein, 2004). In this study, we computed the displacement, strain and stress fields produced by dislocation sources embedded in a mixed elastic/inelastic layered half-space (Wang et al., 2003; Wang et al., 2005). We use the elasticviscoelastic correspondence principle (Christensen, 1982), which states that a linear viscoelastic boundary-value problem can be solved by adopting the associated elastic solutions in which the elastic moduli are replaced by the Laplace or Fourier transformed complex moduli. The time-domain solutions are then obtained using the inverse Fast Fourier Transform.

Once the components of the stress tensor have been calculated, these quantities can be used to define the Coulomb stress change $\left(\Delta \sigma_{c}\right)$ as:

$$
\Delta \sigma_{\mathrm{c}}=\Delta \tau+\mu^{\prime} \Delta \sigma_{\mathrm{N}}
$$

where $\tau$ is the shear stress, $\sigma_{N}$ is the normal stress and $\mu^{\prime}$ is the effective (or apparent) coefficient of friction. When Coulomb stresses surpass a certain critical value, failure occurs. 
Normal and shear stresses are positive when the fault is unclamped and in the corresponding slip direction respectively, so that both positive normal and shear stresses encourage failure. The orientation of a known fault can be used to define the reference system to calculate normal and shear stresses. When no target fault is considered, Coulomb stresses can be calculated on so called "optimally oriented fault planes”, obtaining the direction in which Coulomb stress is at its maximum. This approach is useful to analyse the correlation between Coulomb stress changes and aftershock distribution, since it can be assumed that a sufficient number of small faults with all orientations exist, and that the faults optimally oriented for failure will be most likely to slip in small earthquakes. The calculation of the optimum directions implies knowledge of the pre-existing regional stress field (King et al., 1994).

The effective coefficient of friction is often assumed to be constant in a given area, and it is utilized to include unknown effects of pore-fluid pressure in the crust (Harris, 1998). This parameter is not a material constant, as often implicitly assumed, and its relationship with pore pressure is not simple (Beeler et al., 2000; Cocco and Rice, 2002). A common simplification is to assume that the change in pore pressure is proportional to the normal stress. Under this assumption, $\mu^{\prime}$ is related to the friction coefficient $\mu$ through the Skempton coefficient B as follows:

$$
\mu^{\prime}=\mu(1-B)
$$

in which $\mathrm{B}$ describes the presence of fluids in rock, with $\mathrm{B}=0$ for completely drained rocks and $\mathrm{B}=1$ for the maximum possible presence of fluids. A coefficient of friction of $\mu=0.85$ from laboratory values (Byerlee, 1978 ) and a moderate pore pressure $(\mathrm{B} \sim 0.5)$ lead to a value of $\mu^{\prime}=0.4$. However, if fluids are expelled from the fault zone, the value for $\mu^{\prime}$ will increase up to that of $\mu$. 


\section{Model parameters}

The layered model used for our calculations is described by the rock parameters summarised in Fig. 3 (Milkereit et al., 2000; Milkereit et al., 2004). Concerning the rheological properties, we first considered a medium with a strong viscoelastic lower crust and a weak viscoelastic mantle (hereinafter Model 1). However, although other authors have favoured similar stratification for their studies (e.g. Freed and Lin, 2001; Pollitz and Sacks, 2002), there is also the possibility that the most appropriate description of the medium is the opposite, with a weak lower crust and a strong mantle (Deng et al., 1998; Deng et al., 1999; Zeng, 2001), or that the lithosphere should be considered elastic over its whole depth (Casarotti and Piersanti, 2003). For this reason, we also considered two models incorporating these options (respectively Model 2 and Model 3). In all the cases, viscoelastic layers are modelled as Maxwell bodies.

Fault rupture locations and geometry, as well as slip distribution, were obtained from tectonic and geological maps and published field observations (see Table 1). We modelled the tectonic stress loading with the steady slip over the depth range 17 to $100 \mathrm{~km}$. The slip increases from zero at $17 \mathrm{~km}$ depth to its full magnitude at a depth $35 \mathrm{~km}$. The magnitude of the slip on the NAF was taken from GPS interpretations (Flerit et al., 2003; Flerit et al., 2004).

With these parameters, we carried out calculations for a grid of $81 \times 501$ points, with a spacing of approximately $2 \mathrm{~km}$, covering the study region outlined in Fig. 1. We also calculated Coulomb stress changes at a $2 \mathrm{~km}$ spacing along the segments. 


\section{Results}

Fig. 4 illustrates the evolution of the cumulative Coulomb stress changes on vertical fault planes striking in an E-W direction. For these calculations we used Model 1, with $\mu^{\prime}=0.4$ and lower crust and mantle viscosities of $5 \cdot 10^{19} \mathrm{~Pa} \cdot \mathrm{s}$ and $10^{18} \mathrm{~Pa} \cdot \mathrm{s}$, respectively. Calculations were made for $5 \mathrm{~km}$ depth, regarding this depth as a realistic one for earthquake nucleation. Fig. 4a shows the effect of the steady tectonic stress loading over 10 years, to illustrate the influence of this process on the total field. The state of the stress field at the beginning of the sequence is shown in Fig. 4b, where only the elastic response of the medium to the 1939 event is present. The evolution in time is then shown, with snapshots immediately before and after the 1943 event (Fig. 4c and 4d) and after the 1992 event (Fig. 4e). Fig. 4f displays the stress changes due exclusively to viscoelastic relaxation between 1939 and 1992, to appreciate the effect of this process on the total stress field. Values near the NAF typically range from 0.1 to $0.3 \mathrm{MPa}$, greater in magnitude than those corresponding to steady tectonic loading for the same period. After both 1999 events, the situation is the one displayed in Fig. 4g, and the evolution of the field until the present time is shown in Fig. 4h (total stress field) and Fig. 4i (only the effect of the viscoelastic relaxation).

\subsection{Coulomb stress on the rupture surfaces}

We calculated the Coulomb stress change on the ruptures of the events posterior to 1939 and separately assessed the influence of tectonic, elastic and viscoelastic loading. We regarded positive stress values below $0.01 \mathrm{MPa}$ as not significant, since steady tectonic loading can cause such amounts of stress over a very short period of time (Stein et al., 1997). 
Table 2 compiles values for the maximum and average change stress at the rupture surfaces, whereas Table 3 displays the percentage of the rupture length with $\sigma_{\mathrm{c}} \geq 0.01 \mathrm{MPa}$. The values in both tables display the state immediately before the corresponding event. The values were calculated for Model 1, including results with and without steady tectonic loading, as well as for elastic and viscoelastic media. For the latter, mantle viscosity values from $\eta_{\mathrm{m}}=5 \cdot 10^{17}$ to $10^{19} \mathrm{~Pa} \cdot \mathrm{s}$ were considered, maintaining a constant ratio with the lower crust viscosity of $\eta_{\mathrm{lc}} / \eta_{\mathrm{m}}=50$

The joint effect of tectonic, elastic and viscoelastic loading produces positive average Coulomb stress changes on most of the ruptures. The percentage of the rupture surfaces over the threshold value is at its maximum for $\eta_{m}=5 \cdot 10^{17}-10^{18} \mathrm{~Pa} \cdot \mathrm{s}$. In the case of the 1967 event, varying the viscosity leads to a change in sign for the average Coulomb stress change. Three of the ruptures (1942, 1951 and 1992) show negative average Coulomb stress change regardless of the model assumed.

The whole length of the ruptures of two shocks, namely 1951 and 1992, is in a stress shadow, with the whole surface stressed by less than 0.01 MPa (Table 3). By contrast, the 1957 event shows, independent of the model assumptions, values above this threshold for the whole of its length. The percentage of rupture surface above the threshold for the remaining 6 events depends on the contributions considered for the stress loading, as well as the value of the viscosity when viscoelastic models are used. In general, the influence of viscoelastic relaxation is comparable to that of tectonic loading.

We also carried out calculations using an effective coefficient of friction of 0.6 (Table 4a). This value accounts for a situation where most of the fluids are expelled from the fault zone. The results differ slightly from those presented above. The percentage of the stressed area of the 1943, 1967 and 1999a events increases, and that of the 1944 and 1999b shocks decreases. The total stress field on the rupture of the 1999b event decreases, so that the considered 
percentage decreases from $71 \%$ for $\mu^{\prime}=0.4$ to $64 \%$ for $\mu^{\prime}=0.6$. On the other hand, the elastic contribution to the 1999a event is notably larger, increasing the stressed surface from $40 \%$ for $\mu^{\prime}=0.4$ to $52 \%$ for $\mu^{\prime}=0.6$.

Results for Model 2 and Model 3 (Table 4, b and c) also present punctual differences. Most notably, the stressed area on the rupture of the 1999b event increases to $79 \%$ for Model 2 and decreases to 57\% for Model 3. In Model 2, excluding the effect of tectonic loading, the stressed surface increases for the 1942 and 1967 events in 7\% and 3\% respectively, and decreases for the 1943, 1944 and 1999a events in 12\%, 5\% and 2\%, respectivelly.

\subsection{Coulomb stress on the epicentres}

Figure 5 displays the time evolution of the Coulomb stress at the epicentres of the events posterior to 1939. For 8 out of the 9 epicentres, the effect of the corresponding rupture is a stress release. The exception is the 1951 earthquake. Also, the epicentres of 7 out of 9 earthquakes are stressed with high $\sigma_{\mathrm{c}}$ values, although there are differences regarding its magnitude: Epicentres of the events on the central and eastern part of the NAF (1942, 1943 and 1944) as well as 1999b were loaded below $0.1 \mathrm{MPa}$ before the rupture took place. The epicentres for 1957 and 1967, on the other hand, stored stresses up to values around 0.2 MPa, and up to 0.3 MPa for the 1999a epicentre, before the earthquakes occurred.

In general, it can be observed that the increase in magnitude of $\Delta \sigma_{\mathrm{c}}$ due to viscoelastic relaxation is comparable and in cases larger than that due to steady tectonic loading (compare thin dashed and solid lines).

\subsection{The 1999 Izmit and Düzce events}


The most recent earthquakes of the westwards migrating sequence were the 1999 Mw = 7.4 Izmit/Kocaeli (1999a) and the Mw = 7.1 Düzce (1999b) events. Figure 6 shows the state of the total cumulative $\Delta \sigma_{\mathrm{c}}$ field for optimally oriented fault planes, as well as the stress load on the rupture surfaces, immediately before both events. We assumed a $10 \mathrm{MPa}$ uniaxial compression $\mathrm{N} 120^{\circ} \mathrm{E}$ oriented regional stress field for the calculation of the optimally oriented fault planes (Stein et al., 1997; Hubert-Ferrari et al., 2000; Pinar et al., 2001). Most of the surface of the faults involved in the 1999a event were subjected to high Coulomb stresses at the moment of the earthquake (Fig. 6a). With the exception of the Sapanca-Akyazi segment, the rest of the rupture length were loaded with stress values over $0.1 \mathrm{MPa}$. Moreover, the Izmit-Sapanca Lake segment, were the epicentre was located, as well as its surroundings, were subjected to stresses over 0.3 MPa. The $1999 \mathrm{~b}$ event, on the contrary, was mostly unloaded, the Coulomb stresses in this area released by the 1944, 1957 and 1967 events. The stress changes caused by the 1999a shock induced important changes on the 1999b rupture. Stresses on the coming rupture were larger than before the 1999a shock took place (Fig. 6b), including the epicentre of the earthquake (Fig. 5).

The local $M \geq 2$ seismicity (KOERI, 2005) correlated with the state of the $\Delta \sigma_{c}$ field before the 1999a event (Fig. 6a). In addition, there was an important cluster of activity in the place where the epicentre of the 1999a event was going to take place. This correlation with $\Delta \sigma_{\mathrm{c}}$ was weaker before the 1999b event (Fig. 6b). It should be noticed that the displayed seismicity ranges from 0 to $17 \mathrm{~km}$ depth. In deeper regions the calculated $\Delta \sigma_{\mathrm{c}}$ field might not be representative.

\subsection{The Marmara Sea region}


The current situation in the Marmara Sea region according to our computations is displayed on Fig. 7a, for optimally oriented fault planes and for the two segments of the NAF in the region. We assumed a $10 \mathrm{MPa}$ uniaxial compression $\mathrm{N} 120^{\circ} \mathrm{E}$ oriented regional stress field. Most of the region shows high stress values. The lobe of negative $\sigma_{\mathrm{c}}$ in the direction of the Prince Islands, induced by the 1999a event, disappears due to the joint effect of steady tectonic loading and viscoelastic relaxation (compare Fig.7a with Fig. 4g and Fig. 6b). However, the effect of tectonic loading (Fig. 7b, for 10 years), is not as important as the stress changes induced by post-seismic stress relaxation. Fig. 7c and 7d, respectively 5 and 10 years after the last event of the sequence, show that the viscoelastic relaxation increases the stresses in the region at a faster rate than steady tectonic loading.

The local $M \geq 2$ seismicity between 0 and $17 \mathrm{~km}$ deep (KOERI, 2005) correlates with the calculated Coulomb stress change, with high activity rates associated with the lobe of large $\Delta \sigma_{\mathrm{c}}$ values at the western end of the 1999a rupture $\left(\Delta \sigma_{\mathrm{c}} \geq 0.3 \mathrm{MPa}\right)$, and more activity, in general, for areas with $\Delta \sigma_{\mathrm{c}} \geq 0.1 \mathrm{MPa}$.

\section{Discussion}

\subsection{Coulomb stress on the rupture surfaces and on the epicentres}

In general, the Coulomb stress criterion explains the triggering of subsequent earthquakes by preceding ones. Almost all rupture surfaces, or a large percentage of them, and/or their epicentres, were strongly stressed at the moment of the shock (Table 3 and Fig. 5). It should be noted that only the rupture surface of the 1957 event was stressed over its whole surface 
(Table 3). For most of the events, the rest of the surface was probably dynamically activated during the shock, as described by the general asperity model (Lay and Kanamori, 1981).

We observed that tectonic loading and viscoelastic relaxation increased the stressed surface by a comparable percentage, with the exception of the 1943 and 1944 events (Table 3). For these two earthquakes, the effect of steady tectonic loading is much more important than that from viscoelastic relaxation. This is due to two factors: first, the time interval between these shocks and earlier events in the sequence is too short for viscoelastic relaxation to have a more important effect (Fig. 5); second, the rupture surfaces of the two earthquakes were notable long, and mainly their easternmost ends were loaded by the previous ruptures. For these two events, as well as for the 1939 earthquake, the steady tectonic loading during the preceding centuries seems to be the determining factor for the extension of the rupture surface, rather than the calculated Coulomb stress changes.

The 1951 and the 1992 events present rupture surfaces that are totally unloaded, independent of the assumptions made. The Coulomb stress changes approach, as applied in this study, cannot provide a justification for the occurrence of these events. The 1951 shock seems to have taken place away from the main NAF. Some authors model this shock as a reverse slip event (Stein et al., 1997), striking parallel to the NAF. It seems therefore unrealistic that it might have been caused by the dominant right-lateral strike slip tectonic regime. Also, Fig. 5 shows that the rupture of the 1951 event produces a stress increase at the epicentre of the event, showing the inconsistency between the values used for the geometry of the rupture and the location of the epicentre. Unfortunately, information about the rupture surface is scarce (Barka and Kadinsky-Cade, 1988), and none of the different epicentral locations available (Ambraseys, 1970; McKenzie, 1972; Dewey, 1976, Kandili Observatory, ERD Turkey, USGS) solved this problem. 
The event in 1992 ruptured in the region at the easternmost part of the 1939 event. According to our calculations, the stress released in 1939 was high enough to prevent the 1992 earthquake taking place. This may be due to an inadequate modelling of the slip distribution of the 1939 shock in this area, but measurements and estimates of the slip on the surface in this region are insufficient (Barka, 1996). In addition, the 1992 event did not provide surface expressions of the rupture (Grosser et al., 1998), so it might not be correct to identify its rupture with that of the 1939 event, as we did. Another potentially important factor is the seismicity further to the east, and on the EAF, south of the 1992 shock. At least 3 strong events took place in these areas between 1939 and 1992, in 1949, 1966 and 1971 (Dewey, 1976), and they might have had a significant influence on the Coulomb stress on the 1992 rupture surface. However, recent studies show that fault distribution in the region east of the 1992 event might be more complex than the one traditionally assumed (Milkereit et al., 2004). Finally, other authors also suggest that deep steady slip may not be adequate to estimate the stress changes due to steady tectonic loading (Nalbant et al., 2005). For these reasons, it is unlikely that we would improve our understanding of this region by broadening our study area further to the East. Other than this, it would introduce several additional unknown parameters into our study. A more detailed study of this concrete region, similar to the one carried out by (Nalbant et al., 2005), would be necessary to better understand the influence of viscoelastic relaxation in this area.

We tested the stability of our results by comparing different models. The role of the effective coefficient of friction is not trivial, because it modulates the contribution of the normal stress to the Coulomb stress. In this sequence of earthquakes, the influence of the value for $\mu^{\prime}$ is very limited (Table 4a), with the exception of both events in 1999. The reason for this is the relative location of the rupture surfaces. At the centre and east of the study region, the events in the sequence fall in line along the NAF, with each event's rupture along 
the previous ones. Normal stresses are small in this direction, hence Coulomb stress change is basically governed by shear stress change, and the influence of $\mu^{\prime}$ disappears. On the other hand, the events of 1999 took place in a region where the geometry of the NAF is more complicated, so that the normal stress field gains importance when calculating $\Delta \sigma_{c}$, and the choice for the value of $\mu$ ' has a consequence on the results.

Changes in the properties of the medium (Table $4 \mathrm{~b}$ and c) also led to punctual changes in the results. Differences between results for Model 1 and Model 3 are not significant, but Model 2 gave results that differ significantly from those of Model 1. However, the percentage of the stressed area on the rupture surfaces does not systematically increase or decrease with one of the models, so that we cannot extract information about the rheological stratification of the region from the analysis of the Coulomb stress changes.

\subsection{The 1999 Izmit and Düzce events}

If we assume that an important part of the rupture surface must be stressed for an earthquake to take place, then Model 2 with $\eta_{\mathrm{lc}}=10^{18} \mathrm{~Pa} \cdot \mathrm{s}$ or Model 1 with $\eta_{\mathrm{m}}=5 \cdot 10^{17} \mathrm{~Pa} \cdot \mathrm{s}$ are the favoured models to explain the triggering of the 1999b event. In these cases, $79 \%$ of the rupture is stressed (Table 4). When Model 2 with $\eta_{\mathrm{lc}}=5 \cdot 10^{17} \mathrm{~Pa} \cdot \mathrm{s}$ is used, we find that this increases to $93 \%$. For other events, values of the viscosity of the weak layer lower than $10^{18} \mathrm{~Pa} \cdot \mathrm{s}$ do not lead to noteworthy improvements.

The local seismicity around the area of both 1999 events correlates with the calculated $\Delta \sigma_{\mathrm{c}}$ before the 1999a shock (Fig. 6a). After this event and before the 1999b event the correlation is less apparent. Also, the size of the fraction of the 1999b rupture surface with $\Delta \sigma_{\mathrm{c}} \geq 0.01 \mathrm{MPa}$ is very sensitive to the effective coefficient of friction, as well as to the viscosity of the lower crust and mantle (Tables 3 and 4). 
All of these factors may be an indication that other time-dependent processes, such as afterslip, ductile creep at depth or poro-elastic diffusion processes, might have played an important role in the triggering of the 1999b event. Poro-elastic rebound has proven to have an important role in the first months after an earthquake (Peltzer et al., 1998; Jonsson et al., 2003). Given the short time interval between the 1999a and 1999b events, it might be necessary to consider its effects. There is also the possibility that our modelling approach is too coarse for these events or this region, and that a more detailed analyses must be carried out, taking into account a more detailed geometry and slip distribution for the events and/or additional information about the rheological properties of the lower crust and mantle in the area.

\subsection{The Marmara Sea region}

The local seismicity in the Marmara Sea region correlates with the Coulomb stress change (Fig 7a). A purely elastic approach when calculating the state of the stress field neglects the important stress changes due to viscoelastic relaxation. These process loaded the eastern part of the Marmara Sea region with stresses over $0.1 \mathrm{MPa}$ (Fig. 7c). Also, the viscoelastic effect is comparable or even larger than the stress increase due to tectonic loading (compare Fig. 7b and 7c). Both processes generate stress changes that differ in the pattern: the influence of viscoelastic relaxation is more important to the east of the Marmara Sea region, whereas tectonic loading increases $\sigma_{\mathrm{c}}$ in a more homogeneous way. The eastern segment of the NAF in the Marmara Sea, which was already strongly stressed $\left(\Delta \sigma_{c} \geq 0.3 \mathrm{MPa}\right.$, Fig. 7a), is currently being loaded at a much faster rate than the one corresponding to tectonic loading alone (Figs. 7c and 7d). Accordingly, stress changes due to viscoelastic relaxation should be taken into account in studies focusing on the state of the Coulomb stress field in this region. 


\section{Conclusions}

Our analysis presents several improvements in relation with similar works. We consider a whole sequence of earthquakes instead of single pairs of events, we used a horizontally stratified medium and include the time-dependent effects of viscoelastic relaxation. Our results show that the effects of the latter are comparable or even greater in magnitude than the stress changes induced by steady tectonic loading during the interseismic phase of the earthquake cycle (Figs. 4, 5 and 7). Viscoelastic relaxation should therefore not be neglected.

The Coulomb stress failure criterion provides good results in this area and for this sequence of events, but considering only elastic stress changes can neglect an important part of the actual stress increase/decrease. For the case of the Marmara Sea region, the current rate of stress loading is governed by viscoelastic relaxation rather than tectonic loading. Accordingly, this result should be taken into account by seismic hazard-assessment studies in this region.

\section{Acknowledgments}

We are grateful to Helmut Grosser, Stefano Parolai and Sandra Richwalski for discussions and advice about the manuscript. This work was supported by the Deutsche Forschungsgemeinschaft under grant SFB 526 (Collaborative Research Centre 'Rheology of the Earth - from the Upper Crust to the Subduction Zone', subproject C5) at the Ruhr University Bochum, and by the GeoForschungsZentrum Potsdam. 


\section{References}

Alsan, E., Tezucan, L., Bath, M., 1976. An earthquake catalogue for Turkey for the interval 1913-1970.

Tectonophysics, 31 (1-2): T13-T19.

Ambraseys, N.N., 1970. Some characteristic features of the Anatolian fault zone. Tectonophys., 9: 143-165.

Ambraseys, N.N., Finkel, C.F., 1991. Long-term seismicity of Istanbul and of the Marmara Sea region. Terra Nova, 3 (5): 527-539.

Ambraseys, N.N., Finkel, C.F., 1995. The Seismicity of Turkey and Adjacent Areas - A Historical Review, 1500-1800. M. S. Eren Publications and Books, Istanbul.

Ambraseys, N.N., Zatopek, A., 1969. The Mudurnu valley, west Anatolia, Turkey, earthquake of 22 July 1967. Bulletin of the Seismological Society of America, 59 (2): 521-589.

Armijo, R., Flerit, F., King, G., Meyer, B., 2003. Linear elastic fracture mechanics explains the past and present evolution of the Aegean. Earth and Planetary Science Letters, 217 (1-2): 85-95.

Armijo, R., Pondard, N., Meyer, B., Uçarkus, G., Lépinay, B.M.d., Malavieille, J., Dominguez, S., Gustcher, M.A., Schmidt, S., Beck, C., Çagatav, N., Çakir, Z., Imren, C., Eris, K., Natalin, B., Özalaybey, S., Tolun, L., Lefèvre, I., Seeber, L., Gasperini, L., Rangin, C., Emre, O., Sarikavak, K., 2005. Submarine fault scarps in the Sea of Marmara pull-apart (North Anatolian Fault): Implications for seismic hazard in Istanbul. Geochem. Geophys. Geosys., 6 (6), Q06009, doi:10.1029/2004GC000896.

Ayhan, M.E., Buergmann, R., McClusky, S., Lenk, O., Aktug, B., Herece, E., Reilinger, R.E., 2001. Kinematic of the Mw = 7.2, 12 November 1999, Duzce, Turkey earthquake. Geophysical Research Letters, 28 (2): 367 370.

Barka, A., 1996. Slip distribution along the North Anatolian fault associated with large earthquakes of the period 1939-1967. Bull. Seism. Soc. Am., 86: 1238-1254.

Barka, A., Kadinsky-Cade, K., 1988. Strike-slip fault geometry in Turkey and its influence on earthquake activity. Tectonics, 7: 663-684.

Barka, A.A., Akyuz, H.S., Altunel, E., Sunal, G., Cakir, Z., Dikbas, A., Yerli, B., Armijo, R., Meyer, B., de, C.J.B., Rockwell, T.K., Dolan, J.R., Hartleb, R.D., Dawson, T.E., Christofferson, S.A., Tucker, A., Fumal, T.E., Langridge, R.M., Stenner, H.D., Lettis, W., Bachhuber, J., Page, W.D., 2002. The surface rupture and slip distribution of the 17 August 1999 Izmit earthquake (M 7.4), North Anatolian Fault. Bull. Seism. Soc. Am., 92 (1): 43-60. 
Barrientos, S.E., Plafker, G., Lorca, E., 1992. Postseismic coastal uplift in Southern Chile. Geophys. Res. Lett., 19: 701-704.

Beeler, N.M., Simpson, R.W., Hickman, S.H., Lockner, D.A., 2000. Pore fluid pressure, apparent friction, and Coulomb failure. Journal of Geophysical Research B: Solid Earth, 105 (11).

Belardinelli, M.E., Bizzarri, A., Cocco, M., 2003. Earthquake triggering by static and dynamic stress changes. J. Geophys. Res., 108 (B3): ESE 1-1 to ESE 1-16.

Belardinelli, M.E., Cocco, M., Coutant, O., Cotton, F., 1999. Redistribution of dynamic stress during coseismic ruptures: Evidence for fault interaction and earthquake triggering. Journal of Geophysical Research, 104 (B7): 14925-14945.

Byerlee, J., 1978. Friction of Rocks. Pageoph, 116: 615-626.

Casarotti, E., Piersanti, A., 2003. Postseismic stress diffusion in Chile and South Peru. Earth and Planetary Science Letters, 206 (3-4): 325-333.

Christensen, R.M., 1982. Theory of viscoelasticity. An introduction. Academic Press, New York, Second.

Cocco, M., Rice, J.R., 2002. Pore pressure and poroelasticity effects in Coulomb stress analysis of earthquake interactions. Journal of Geophysical Research B: Solid Earth, 107 (2): 2-1.

Deng, J., Gurnis, M., Kanamori, H., Hauksson, E., 1998. Viscoelastic flow in the lower crust after the 1992 Landers, California, earthquake. Science, 282 (5394): 1689-1692.

Deng, J., Hudnut, K., Gurnis, M., Hauksson, E., 1999. Stress loading from viscous flow in the lower crust and triggering of aftershocks following the 1994 Northridge, California, earthquake. Geophysical Research Letters, 26 (21): 3209-3212.

Dewey, J.W., 1976. Seismicity of northern Anatolia. Bull. Seism. Soc. Am., 66: 843-868.

Flerit, F., Armijo, R., King, G., Meyer, B., 2004. The mechanical interaction between the propagating North Anatolian Fault and the back-arc extension in the Aegean. Earth planet. Sci. Lett., 224 (3-4): 347-362.

Flerit, F., Armijo, R., King, G.C.P., Meyer, B., Barka, A., 2003. Slip partitioning in the Sea of Marmara pullapart determined from GPS velocity vectors. Geophysical Journal International, 154 (1): 1-7.

Freed, A.M., Lin, J., 2001. Delayed triggering of the 1999 Hector Mine earthquake by viscoelastic stress transfer. Nature, 411 (6834): 180-183, (See also: E. Harding Hearn, Nature, same issue, p. 150.).

Gokasan, E., Ustaömer, T., Gazioglu, C., Yucel, Z.Y., Öztürk, K., Tur, H., Ecevitoglu, B., Tok, B., 2003. Morpho-tectonic evolution of the Marmara Sea inferred from multi-beam bathymetric and seismic data. GeoMarine Letters, 23 (1): 19-33. 
Grosser, H., Baumbach, M., Berckhemer, H., Baier, B., Karahan, A., Schelle, H., Krueger, F., Paulat, A., Michel, G., Demirtas, R., Gencoglu, S., Yilmaz, R., 1998. The Erzincan (Turkey) earthquake (M (sub s) 6.8) of March 13, 1992 and its aftershocks sequence. Pure and Applied Geophysics, 152 (3): 465-505.

Hardebeck, J.L., 2004. Stress triggering and earthquake probability estimates. J. Geophys. Res., 109 (B4).

Harris, R.A., 1998. Introduction to special section: Stress triggers, stress shadows, and implications for seismic hazard. J. Geophys. Res., 103 (B10): 24347-24358.

Harris, R.A., Simpson, R.W., Reasenberg, P.A., 1995. Influence of static stress changes on earthquake locations in southern Caliifornia. Nature, 375 (6528): 221-224.

Healy, J.H., Rubey, W.W., Griggs, D.T., Raleigh, C.B., 1968. The Denver earthquakes. Science, 161: 13011310.

Horasan, G., Gulen, L., Pinar, A., Kalafat, D., Ozel, N., Kuleli, H.S., Isikara, A.M., 2002. Lithospheric structure of the Marmara and Aegean regions, western Turkey. In: The Izmit, Turkey, earthquake of 17 August 1999. Seismological Society of America, Berkeley, CA, United States, pp. 322-329.

Hubert-Ferrari, A., Barka, A., Jacques, E., Nalbant, S.S., Meyer, B., Armijo, R., Tapponnier, P., King, G.C.P., 2000. Seismic hazard in the Marmara Sea region following the 17 August 1999 Izmit earthquake. Nature, 404 (6775): 269-273.

Jackson, J., McKenzie, D., 1988. The relationship between plate motions and seismic moment tensors, and the rates of active deformation in the Mediterranean and Middle East. Geophys. J., 93: 45-73.

Jonsson, S., Segall, P., Pedersen, R., Bjornsson, G., 2003. Post-earthquake ground movements correlated to porepressure transients. Nature (London), 424 (6945): 179-183.

Karahan, A.E., Berckhemer, H., Baier, B., 2001. Crustal structure at the western end of the North Anatolian fault zone from deep seismic sounding. Annali di Geofisica (1993), 44 (1): 49-68.

Kasahara, K., 1975. Aseismic faulting following the 1973 Nemuro-oki earthquake, Hokkaido, Japan (A possibility). Pageoph, 113: 127-139.

Kaypak, B., Eyidogan, H., 2005. One-dimensional crustal structure of the Erzincan basin, Eastern Turkey and relocation of the 1992 Erzincan earhtquake $(\mathrm{Ms}=6.8)$ aftershock sequence. Physics of the Earth and Planetary Interiors, 151: 1-20.

King, G.C.P., Stein, R.S., Lin, J., 1994. Static stress changes and the triggering of earthquakes. Bull. Seism. Soc. Am., 84: 935-953. 
KOERI, 2005. Recent earthquakes in Turkey. Bogazici University, Kandilli Observatory and Earthquake Research Institute. http://www.koeri.boun.edu.tr/sismo/defaulteng.htm

Lay, T., Kanamori, H., 1981. An asperity model of large earthquake sequences. In: D.W. Simpson and P.J. Richards (Eds.), Earthquake Prediction. Maurice Ewing Series. AGU, Washington, D.C., pp. 579-592.

Le Pichon, X., Sengor, A.M.C., Demirbag, E., Rangin, C., Imren, C., Armijo, R., Gorur, N., Cagatay, N., Mercier, d.L.B., Meyer, B., Saatcilar, R., Tok, B., 2001. The active main Marmara Fault. Earth and Planetary Science Letters, 192 (4): 595-616.

Lin, J., Stein, R.S., 2004. Stress triggering in thrust and subduction earthquakes and stress interaction between the southern San Andreas and nearby thrust and strike-slip faults. J. Geophys. Res., 109 (B2).

Linde, A.T., Silver, P.G., 1989. Elevation changes and the Great 1960 Chilean earthquake: Support for aseismic slip. Geophys. Res. Lett., 16: 1305-1308.

McClusky, S., Balassanian, S., Barka, A., Demir, A., Ergintav, S., Georgiev, I., Gurkan, O., Hamburger, M., Hurst, K., Kahle, H., Kastens, K., Kekelidze, G., King, R., Kotzev, V., Lenk, O., Mahmoud, S., Mishin, A., Nadariya, M., Ouzounis, A., Paradissis, D., Peter, Y., Prilepin, M., Reilinger, R., Sanli, I., Seeger, H., Tealeb, A., Toksöz, M.N., Veis, G., 2000. Global Positioning System constraints on plate kinematics and dynamics in the eastern Mediterranean and Caucasus. J. Geophys. Res., 105 (B3): 5695-5719.

McKenzie, D.P., 1972. Active tectonics of the Mediterranean region. Geophys. J. R. astr. Soc., 30: 109-185.

Milkereit, C., Grosser, H., Wang, R., Wetzel, H.-U., Woith, H., Karakisa, S., Zünbül, S., Zschau, J., 2004.

Implications of the 2003 Bingöl Earthquake for the Interaction between the North and East Anatolian Faults. Bull. Seism. Soc. Am., 6: 2400-2406.

Milkereit, C., Zünbül, S., Karakisa, S., Iravul, Y., Zschau, J., Baumbach, M., Grosser, H., Günther, E., Umutlu, N., Kuru, T., Erkul, E., Klinge, K., Ibs-von Seht, M., Karahan, A., 2000. Preliminary aftershock analysis of the Mw=7.4 Izmit and Mw=7.1 Düzce earthquake in western Turkey. In: A. Barka, Ö. Kozaci, S. Akyüz and A. Altunel (Eds.), The 1999 Izmit and Düzce Earthquakes: preliminary results. Istanbul Technical University, pp. 179-187.

Mogi, K., 1968. Migration of seismic activity. Bull. Earthq. Res. Inst., 46: 53-74.

Muller, J.R., Aydin, A., Maerten, F., 2003. Investigating the transition between the 1967 Mudurnu Valley and the 1999 Izmit earthquakes along the North Anatolian fault with static stress changes. Geophys. J. Int., 154 (2): 471-482. 
Nalbant, S.S., McCloskey, J., Steacy, S., 2005. Lessons on the calculation of the static stress loading from the 2003 Bingol, Turkey earhtquake. Earth and Planetary Science Letters, 235: 632-640.

Parsons, T., Toda, S., Stein, R.S., Barka, A., Dieterich, J.H., 2000. Heightened odds of large earthquakes near Istanbul: an interaction-based probability calculation. Science, 288 (5466): 661-665.

Peltzer, G., Rosen, P., Rogez, F., Hudnut, K., 1998. Poroelastic rebound along the Landers 1992 earthquake surface rupture. J. Geophys. Res., 103 (B12): 30131-30146.

Pinar, A., Honkura, Y., Kikuchi, M., 1994. Rupture process of the 1992 Erzincan earthquake and its implication for seismotectonics in eastern Turkey. Geophysical Research Letters, 21 (18): 1971-1974.

Pinar, A., Honkura, Y., Kuge, K., 2001. Seismic activity triggered by the 1999 Izmit earthquake and its implications for the assessment of future risk. Geophys. J. Int., 146 (1): F1-F7.

Pollitz, F.F., Sacks, I.S., 2002. Stress triggering of the 1999 Hector Mine earthquake by transient deformation following the 1992 Landers earthquake. Bull. Seism. Soc. Am., 92 (4): 1487-1496.

Purcaru, G., Berckhemer, H., 1982. Regularity patterns and zones of seismic potential for future large earthquakes in the Mediterranean region. Tectonophys., 85: 1-30.

Raleigh, C.B., Healy, J.H., Bredehoeft, J.D., 1972. Faulting and crustal stress at Rangely, Colorado. In: H.C. Heard, I.Y. Borg, N.L. Carter and C.B. Raleigh (Eds.), Flow and Fracture of Rocks. Geophysical Monograph Series. Am. Geophys. Un., Washington, D. C., pp. 275-284.

Reasenberg, P.A., Simpson, R.W., 1992. Response of regional seismicity to the static stress change produced by the Loma Prieta earthquake. Science, 255 (5052): 1687-1690.

Roth, F., 1983. Oberflächendeformationen und Krustenspannungen in Erdbebengebieten: Ein Modell zur Beschreibung ihrer zeitlichen Änderungen. Dissertation Thesis, Inst. f. Geophys., C.-A.-Univ. Kiel, 184 pp.

Roth, F., 1988. Modeling of stress patterns along the western part of the North Anatolian Fault Zone. Tectonophys., 152: 215-226.

Saroglu, F., Emre, Ö., Kuscu, I., 1992. Active fault map of Turkey. Geological Research Department of the General Directorate of Mineral Research and Exploration, Ankara, Turkey.

Sengör, A.M.C., Görür, N., Saroglu, F., 1985. Strike-slip faulting and related basin formation in zones of tectonic scape: Turkey as a case study. In: T.R. Biddle and N. Christi-Blick (Eds.), Strike-slip deformation, basin formation and sedimentation. Soc. Econ. Paleontol. Mineral., pp. 227-264.

Stein, R.S., 1999. The role of stress transfer in earthquake occurrence. Nature, 402 (6762): 605-609. 
Stein, R.S., Barka, A.A., Dieterich, J.H., 1997. Progressive failure on the North Anatolian fault since 1939 by earthquake stress triggering. Geophys. J. Int., 128 (3): 594-604.

Stein, R.S., King, G.C., Lin, J., 1992. Change in failure stress on the southern San Andreas fault system caused by the 1992 magnitude = 7.4 Landers earthquake. Science, 258 (5086): 1328-1332.

Stein, R.S., King, G.C.P., Lin, J., 1994. Stress triggering of the 1994 M=6,7 Northridge, California, earthquake by its predecessors. Science, 265: 1432-1435.

Thatcher, W., Rundle, J.R., 1984. A viscoelastic coupling model for the cyclic deformation due to periodically repeated earthquakes at subduction zones. J. Geophys. Res., 89: 7631-7640.

Tibi, R., Bock, G., Xia, Y., Baumbach, M., Grosser, H., Milkereit, C., Karakisa, S., Zunbul, S., Kind, R., Zschau, J., 2001. Rupture processes of the 1999 August 17 Izmit and November 12 Duzce (Turkey) earthquakes. Geophysical Journal International, 144 (2): F1-F7.

Toda, S., Stein, R.S., Reasenberg, P.A., Dieterich, J.H., Yoshida, A., 1998. Stress transferred by the 1995 M(w) = 6.9 Kobe, Japan, shock: Effect on aftershocks and future earthquake probabilities. Journal of Geophysical Research B: Solid Earth, 103 (B10): 24543-24565.

Toksöz, M.N., Shakal, A.F., Michael, A.J., 1979. Space-time migration of earthquakes along the North Anatolian fault zone and seismic gaps. Pageoph, 117: 1258-1270.

Umutlu, N., Koketsu, K., Milkereit, C., 2004. The rupture process during the 1999 Düzce, Turkey, earthquake from joint inversion of teleseismic and strong-motion data. Tectonophys., 391: 315-324.

Wang, R., Lorenzo Martín, F., Roth, F., 2003. Computation of deformation induced by earthquakes in a multilayered elastic crust - FORTRAN programs EDGRN / EDCMP. Computers and Geosciences, 29 (2): 195-207.

Wang, R., Lorenzo Martín, F., Roth, F., 2005. A semi-analytical software PSGRN/PSCMP for calculating coand post-seismic deformation on a layered viscoelastic-gravitational half-space. Computers and Geosciences, acepted for publication.

Wright, T., Fielding, E., Parsons, B., 2001. Triggered slip; observations of the 17 August 1999 Izmit (Turkey) earthquake using radar interferometry. Geophysical Research Letters, 28 (6): 1079-1082.

Zeng, Y., 2001. Viscoelastic stress-triggering of the 1999 Hector Mine earthquake by the 1992 Landers earthquake. Geophys. Res. Lett., 28 (15): 3007-3010. 
Figure 1: Map showing the major tectonic elements of Turkey. Anatolia is forced to move towards the Aegean subduction zone, moving along the North and East Anatolian faults. The box shows our study area.

Figure 2: Space-time migration of the considered $10 \mathrm{M}_{\mathrm{s}}>6.5$ earthquakes along the NAF in the period 1939 to 1999 . Thick lines display the events. Thin lines represents the geometry of the North Anatolian Fault used in the calculations (Armijo et al., 2003; Flerit et al., 2003; Flerit et al., 2004). Stars indicate the epicentres of the shocks in the sequence (Dewey, 1976, ERD Turkey, USGS).

Figure 3: Parameters of the horizontally stratified medium. The same stratification values have been applied for different tectonically active areas along the NAF (Milkereit et al., 2000; Milkereit et al., 2004, thick line). Results from other studies are also shown for comparison (Karahan et al., 2001; Horasan et al., 2002; Kaypak and Eyidogan, 2005). We considered a Poisson's ration of 0.25 . The lower crust and the mantle have variable viscosities $\eta_{\mathrm{lc}}$ and $\eta_{\mathrm{m}}$, respectively.

Figure 4: Evolution of the Coulomb stress field since 1939. Calculations were made for fault planes striking in an E-W direction, and the results were evaluated for $5 \mathrm{~km}$ depth. Black thick lines represents all segments used to model the tectonic loading at the NAF. White lines display ruptured segments and red lines unruptured segments, immediately before their activation. Fig. 4a shows the effect of 10 years of steady tectonic loading. The rest of the 
panels display the situation at different points in time: (b) immediately after the 1939 event; (c) before the 1942 event; (d) after the 1942 event; (e) after the 1992 event; (f) effect of viscoelastic relaxation from 1939 to 1992; (g) after the 1999b event; (h) current state of the Coulomb stress field; (i) effect of viscoelastic relaxation from 1939 to 2005.

Figure 5: Time-evolution of Coulomb stress on the epicentres of the considered events (Table 1). Vertical dotted lines display the time of occurrence of each event. The thick solid line shows the development when elastic and viscoelastic stress changes, as well as tectonic loading, are considered. The thin solid line shows the development when the effect from viscoelastic relaxation is not considered. The thin dashed line displays the case where viscoelastic relaxation is considered but tectonic loading is not. The white dot marks the moment and state of stress at the epicentre when the rupture occurs. The value close to the dot is the Coulomb stress at that moment, in MPa.

Figure 6: Coulomb stress change at $5 \mathrm{~km}$ depth on optimally oriented fault planes (colour field, $10 \mathrm{MPa}$ uniaxial compression $\mathrm{N} 120^{\circ} \mathrm{E}$ oriented regional stress field) and on given faults (filled circles). 6a shows the situation before the August $17^{\text {th }}, 1999$ event (1999a), and 6b before the November $12^{\text {th }}$, 1999 shock (1999b). White lines are already ruptured segments. Red stars display the location of the epicentres. Small white dots show the local $\mathrm{M} \geq 2$ seismicity at depths between 0 and $17 \mathrm{~km}$ over six months before the 1999a event (a) and for the period between the 1999a and 1999b shocks (b). Green squares display the location of the Kandilli Observatory and Earthquake Research Institute (KOERI) seismic stations. 
Figure 7: Coulomb stress change at $5 \mathrm{~km}$ depth on optimally oriented fault planes (colour field, $10 \mathrm{MPa}$ uniaxial compression $\mathrm{N} 120^{\circ} \mathrm{E}$ oriented regional stress field), and on given faults (filled circles). The total stress field is displayed in (a); (b) shows the change in Coulomb stresses due to 10 years of steady tectonic loading; (c) and (d) show the cumulative effect of viscoelastic relaxation, for the present time and in 2010 respectively. The white line displays the western end of the 1999a rupture. Small white dots in (a) show the local $M \geq 2$ seismicity for the period 2000-2004 at depths between 0 and $17 \mathrm{~km}$. Green squares display the location of the Kandilli Observatory and Earthquake Research Institute (KOERI) seismic stations. 
Table 1: Parameters of the sequence of earthquakes used

\begin{tabular}{|c|c|c|c|c|c|c|c|}
\hline \multicolumn{2}{|c|}{ date } & \multirow{2}{*}{\begin{tabular}{|l} 
GMT \\
$23: 57$
\end{tabular}} & \multirow{2}{*}{$\begin{array}{c}\text { lat. }\left({ }^{\circ} \mathbf{N}\right) \\
39.80\end{array}$} & \multirow{2}{*}{$\begin{array}{c}\text { lon. }\left({ }^{\circ} \mathbf{E}\right) \\
39.38\end{array}$} & \multirow{2}{*}{$\begin{array}{c}\mathbf{M}_{\mathbf{s}} \\
8.0\end{array}$} & \multirow{2}{*}{$\begin{array}{c}\mathbf{M}_{\mathbf{0}}(\mathbf{N m}) \\
4.72 \cdot 10^{20}\end{array}$} & \multirow{2}{*}{$\begin{array}{c}\text { references } \\
(2),(3),(5),(7)\end{array}$} \\
\hline 1939 & 26 Dec & & & & & & \\
\hline 1942 & $20 \mathrm{Dec}$ & 14:03 & 40.66 & 36.35 & 7.3 & $1.74 \cdot 10^{19}$ & (2), (3), (5), (7) \\
\hline 1943 & $26 \mathrm{Nov}$ & $22: 20$ & 41.05 & 33.72 & 7.6 & $2.51 \cdot 10^{20}$ & (2), (3), (5), (7) \\
\hline 1944 & $01 \mathrm{Feb}$ & 03:23 & 41.00 & 33.22 & 7.6 & $1.48 \cdot 10^{20}$ & (2), (3), (5), (7) \\
\hline 1951 & 13 Aug & 18:33 & 40.86 & 32.68 & 6.7 & $1.22 \cdot 10^{19}$ & (3), (4) \\
\hline 1957 & 26 May & 06:33 & 40.58 & 31.00 & 7.2 & $1.35 \cdot 10^{19}$ & (2), (3), (5), (7) \\
\hline 1967 & $22 \mathrm{Jul}$ & 16:56 & 40.57 & 30.80 & 7.3 & $2.83 \cdot 10^{19}$ & (1), (2), (3), (5), (7), (13) \\
\hline 1992 & $13 \mathrm{Mar}$ & $17: 19$ & 39.71 & 39.60 & 6.9 & $8.11 \cdot 10^{18}$ & (5), (6), (8) \\
\hline 1999 & 17 Aug & 00:01 & 40.70 & 29.91 & 7.8 & $2.15 \cdot 10^{20}$ & (10), (11), (12) \\
\hline 1999 & $12 \mathrm{Nov}$ & 16:57 & 40.79 & 30.21 & 7.3 & $4.67 \cdot 10^{19}$ & (9), (10), (14) \\
\hline
\end{tabular}

Epicentral coordinates are from Dewey (1976) until 1967, with the exception of the 1943 event, for which Dewey’s epicentral coordinates appear to be too far East (Ambraseys, 1970; Alsan et al., 1976; Saroglu et al., 1992). For this event and the more recent ones, we used the coordinates provided by the Earthquake Research Directorate (ERD), Seismological Division, Turkey. $\mathrm{M}_{\mathrm{s}}$ values are from the USGS. $\mathrm{M}_{\mathrm{o}}$ values correspond to the geometry and slip distribution used in the present work, comparable to those of Stein et al. (1997). (The references used: (1) Ambraseys and Zatopek, 1969; (2) Ambraseys, 1970; (3) Dewey, 1976; (4) Barka and Kadinsky-Cade, 1988; (5) Saroglu et al., 1992; (6) Pinar et al., 1994; (7) Barka, 1996; (8) Grosser et al., 1998; (9) Ayhan et al., 2001; (10) Tibi et al., 2001; (11) Wright et al., 2001; (12) Barka et al., 2002; (13) Muller et al., 2003; and (14) Umutlu et al., 2004). 
Table 2: Maximum and average Coulomb stress changes $\left(\Delta \sigma_{c}\right)$ on the ruptures immediately before each event

\begin{tabular}{|c|c|c|c|c|c|c|c|c|c|c|c|c|c|c|c|c|c|}
\hline \multirow{2}{*}{$\begin{array}{c}\text { viscosity } \\
\infty\end{array}$} & \multirow{2}{*}{$\begin{array}{c}1942 \\
0.04-0.63\end{array}$} & \multicolumn{2}{|c|}{1943} & \multicolumn{2}{|c|}{1944} & \multicolumn{2}{|c|}{1951} & \multicolumn{2}{|c|}{1957} & \multicolumn{2}{|c|}{1967} & \multicolumn{2}{|c|}{1992} & \multicolumn{2}{|c|}{ 1999a } & \multicolumn{2}{|c|}{ 1999b } \\
\hline & & 0.06 & 0.02 & 10.34 & 0.28 & -0.73 & -1.35 & 3.56 & 0.68 & 1.40 & -0.06 & -1.48 & -4.69 & 0.60 & 0.15 & 0.32 & -0.05 \\
\hline $5 \cdot 10^{17} \mathrm{~Pa} \cdot \mathrm{S}$ & $0.11-0.51$ & 0.14 & 0.04 & 10.36 & 0.28 & -0.49 & -1.11 & 3.69 & 0.76 & 1.62 & 0.04 & -0.83 & -3.59 & 0.71 & 0.23 & 0.50 & 0.17 \\
\hline $10^{18} \mathrm{~Pa} \cdot \mathrm{s}$ & $0.09-0.54$ & 0.12 & 0.04 & 10.35 & 0.28 & -0.54 & -1.15 & 3.66 & 0.74 & 1.56 & 0.01 & -1.02 & -3.91 & 0.68 & 0.21 & 0.47 & 0.12 \\
\hline $5 \cdot 10^{18} \mathrm{~Pa} \cdot \mathrm{S}$ & $0.06-0.61$ & 0.07 & 0.03 & 10.34 & 0.28 & -0.65 & -1.27 & 3.61 & 0.71 & 1.49 & -0.02 & -1.26 & -4.29 & 0.65 & 0.19 & 0.43 & 0.07 \\
\hline $10^{19} \mathrm{~Pa} \cdot \mathrm{s}$ & $0.05-0.62$ & 0.06 & 0.02 & 10.34 & 0.28 & -0.69 & -1.31 & 3.59 & 0.70 & 1.46 & -0.03 & -1.30 & -4.37 & 0.64 & 0.19 & 0.41 & 0.05 \\
\hline From tect. loading & 0.02 & 0.0 & & 0.0 & & 0.0 & 07 & 0.0 & & 0.1 & 12 & 0.4 & 42 & 0.2 & & 0.2 & 25 \\
\hline
\end{tabular}

Values are for a purely elastic model (infinite viscosity) and for 4 different mantle viscosities, $\eta_{\mathrm{m}}$. The ratio with the lower crust viscosity is kept constant at $\eta_{\mathrm{lc}} / \eta_{\mathrm{m}}=50$. The last line displays the fraction of the results produced by steady tectonic loading. Results are for Model 1 (see text), and an effective coefficient of friction of 0.4 . 
Table 3: Percentage of fault rupture showing $\Delta \sigma_{\mathrm{c}} \geq 0.01 \mathrm{MPa}$

\begin{tabular}{|c|c|c|c|c|c|c|c|c|c|c|}
\hline & viscosity & 1942 & 1943 & 1944 & 1951 & 1957 & 1967 & 1992 & $1999 a$ & $1999 b$ \\
\hline & $\infty$ & 11 & 92 & 95 & 0 & 100 & 75 & 0 & 81 & 29 \\
\hline with & $5 \cdot 10^{17} \mathrm{~Pa} \cdot \mathrm{s}$ & 18 & 93 & 95 & 0 & 100 & 78 & 0 & 82 & 79 \\
\hline tectonic & $10^{18} \mathrm{~Pa} \cdot \mathrm{S}$ & 18 & 93 & 95 & 0 & 100 & 78 & 0 & 81 & 71 \\
\hline \multirow[t]{3}{*}{ loading } & $5 \cdot 10^{18} \mathrm{~Pa} \cdot \mathrm{s}$ & 14 & 93 & 95 & 0 & 100 & 78 & 0 & 81 & 57 \\
\hline & $10^{19} \mathrm{~Pa} \cdot \mathrm{S}$ & 11 & 93 & 95 & 0 & 100 & 75 & 0 & 81 & 50 \\
\hline & $\infty$ & 7 & 13 & 44 & 0 & 100 & 70 & 0 & 40 & 7 \\
\hline without & $5 \cdot 10^{17} \mathrm{~Pa} \cdot \mathrm{S}$ & 18 & 33 & 55 & 0 & 100 & 75 & 0 & 81 & 21 \\
\hline tectonic & $10^{18} \mathrm{~Pa} \cdot \mathrm{S}$ & 14 & 33 & 52 & 0 & 100 & 75 & 0 & 81 & 21 \\
\hline \multirow[t]{2}{*}{ loading } & $5 \cdot 10^{18} \mathrm{~Pa} \cdot \mathrm{S}$ & 11 & 19 & 45 & 0 & 100 & 75 & 0 & 81 & 14 \\
\hline & $10^{19} \mathrm{~Pa} \cdot \mathrm{s}$ & 7 & 18 & 44 & 0 & 100 & 70 & 0 & 66 & 14 \\
\hline
\end{tabular}

Values when including the effects of steady tectonic loading (upper five lines) and when excluding this effects (lower five lines). Model parameters as in Table 2. 
Table 4: Percentage of fault rupture with $\Delta \sigma_{\mathrm{c}} \geq 0.01 \mathrm{MPa}$

\begin{tabular}{|c|c|c|c|c|c|c|c|c|c|c|c|}
\hline & & & 1942 & 1943 & 1944 & 1951 & 1957 & 1967 & 1992 & $1999 a$ & $1999 b$ \\
\hline \multirow{4}{*}{ a } & \multirow{2}{*}{ with tectonic loading } & elas. & 11 & 94 & 89 & 0 & 100 & 78 & 0 & 81 & 29 \\
\hline & & visc. & 18 & 95 & 89 & 0 & 100 & 80 & 0 & 84 & 64 \\
\hline & \multirow{2}{*}{ without tectonic loading } & elas. & 11 & 16 & 43 & 0 & 100 & 73 & 0 & 52 & 7 \\
\hline & & visc. & 14 & 33 & 51 & 0 & 100 & 78 & 0 & 81 & 14 \\
\hline \multirow{2}{*}{$\mathrm{b}$} & with tectonic loading & visc. & 21 & 93 & 95 & 0 & 100 & 80 & 0 & 84 & 79 \\
\hline & without tectonic loading & visc. & 21 & 21 & 47 & 0 & 100 & 78 & 0 & 79 & 21 \\
\hline \multirow[t]{2}{*}{ c } & with tectonic loading & visc. & 18 & 93 & 95 & 0 & 100 & 78 & 0 & 81 & 57 \\
\hline & without tectonic loading & visc. & 14 & 33 & 51 & 0 & 100 & 75 & 0 & 79 & 14 \\
\hline
\end{tabular}

Values for Model 1 with $\mu^{\prime}=0.6$ (a), for Model 2 with $\mu^{\prime}=0.4$ (b), and for Model 3 with $\mu^{\prime}=0.4$ (c). Both elastic and viscoelastic media are considered. The viscosities used are $\eta_{\mathrm{m}}=10^{18} \mathrm{~Pa} \cdot \mathrm{s}$ and $\eta_{\mathrm{lc}} / \eta_{\mathrm{m}}=50$ for (a) and (c), and $\eta_{\mathrm{lc}}=10^{18} \mathrm{~Pa} \cdot \mathrm{s}$ with $\eta_{\mathrm{m}} / \eta_{\mathrm{lc}}=50$ for (b). 


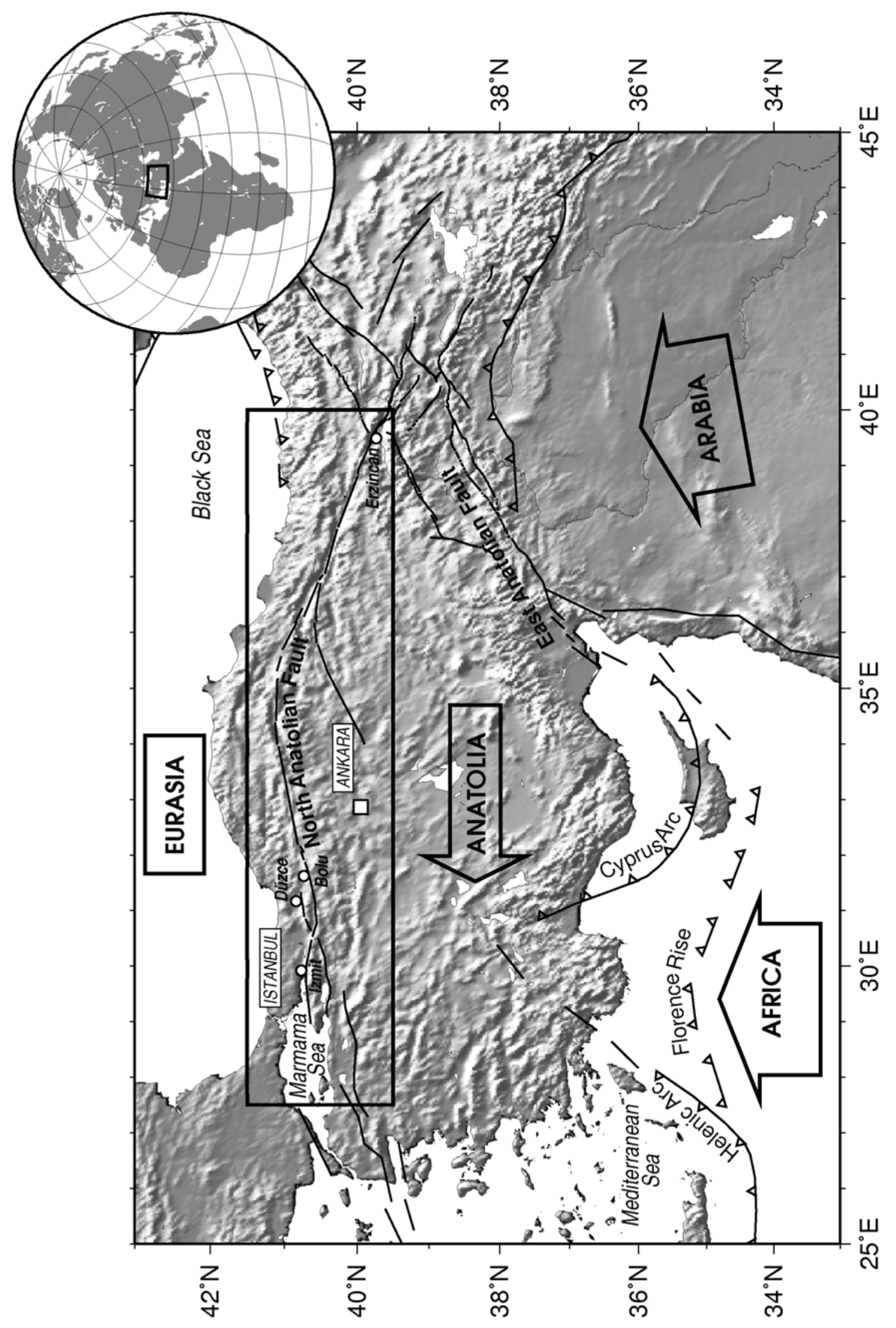

Figure 1 


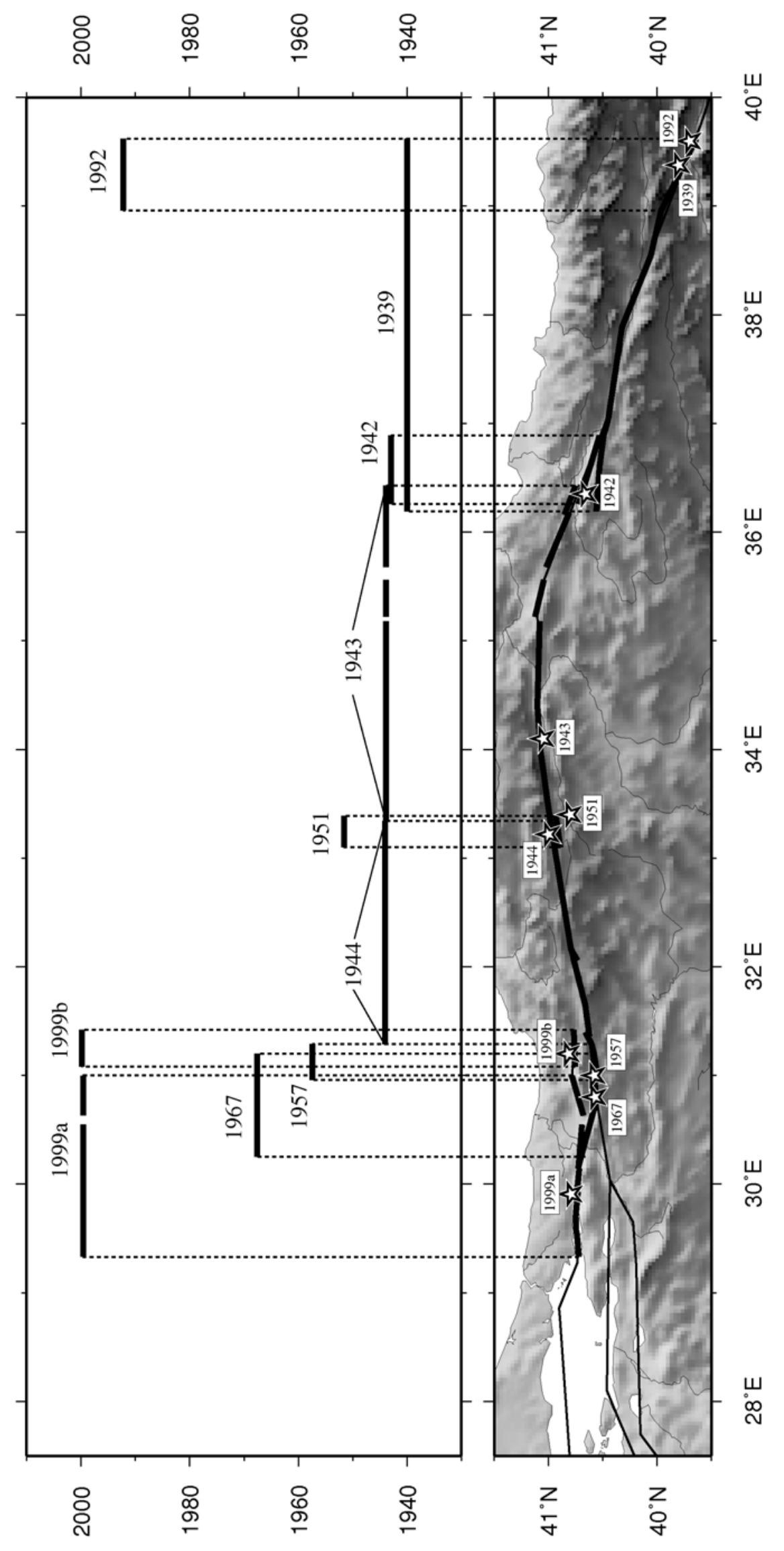

Figure 2 


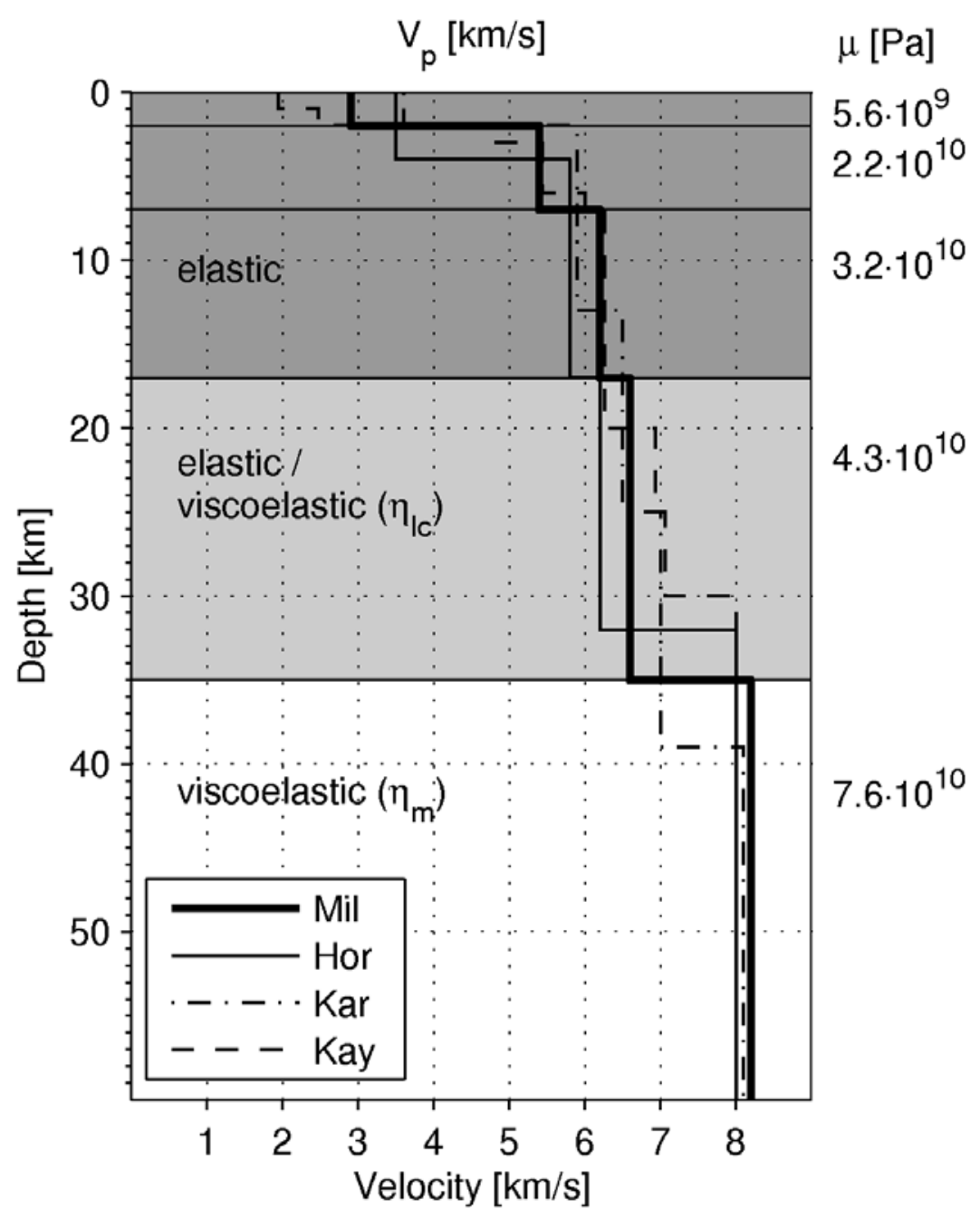

Figure 3 

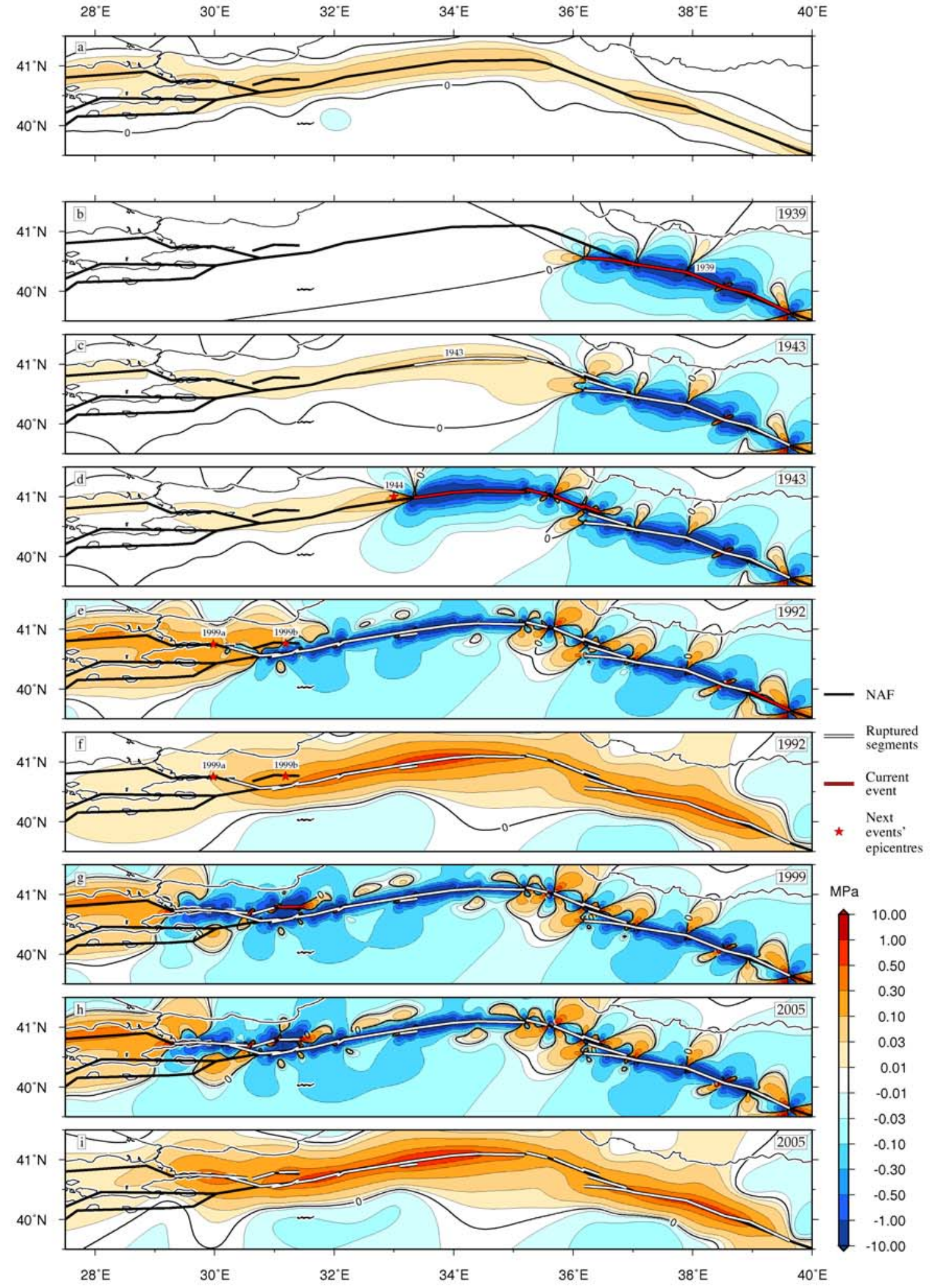

Figure 4 


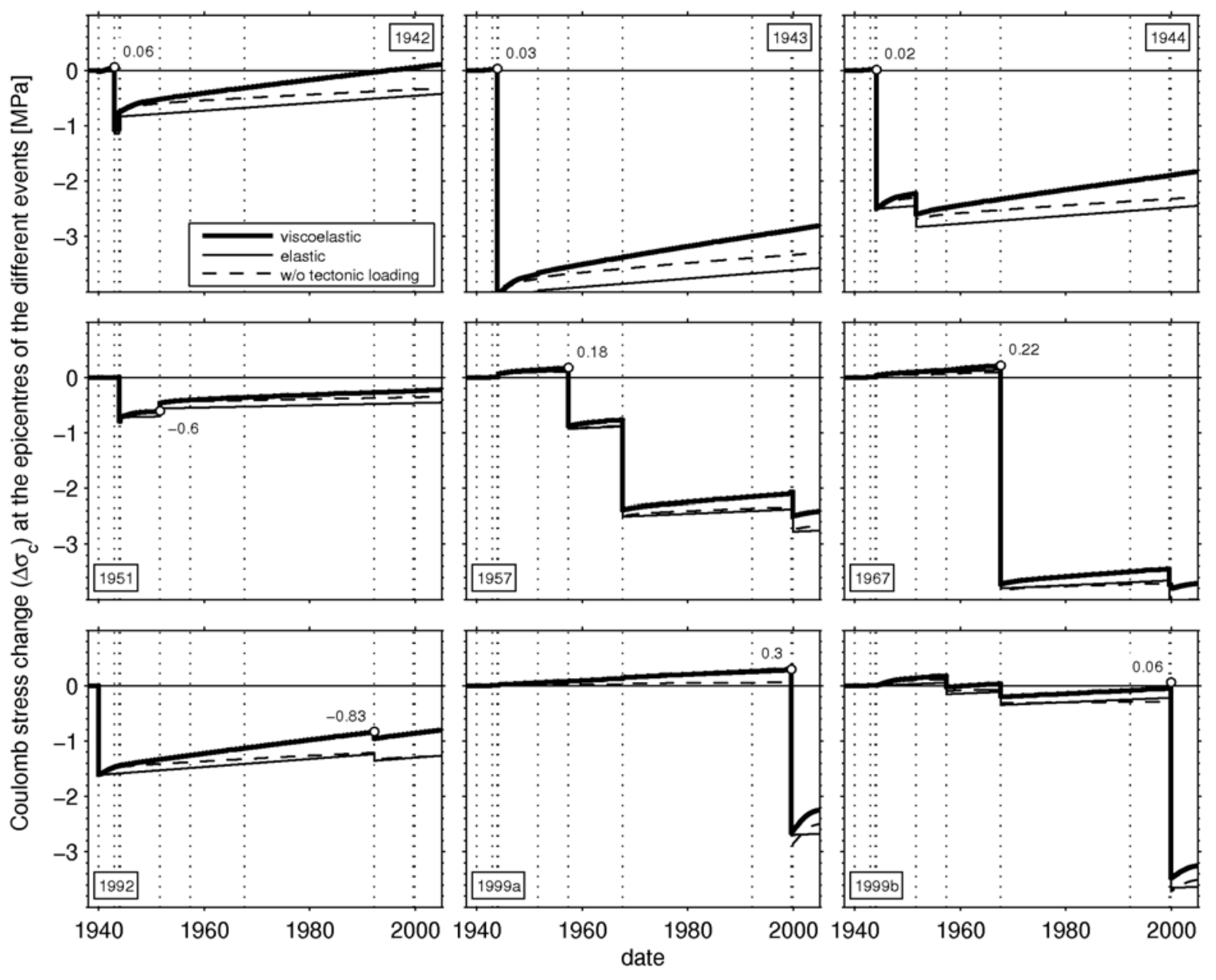

Figure 5 

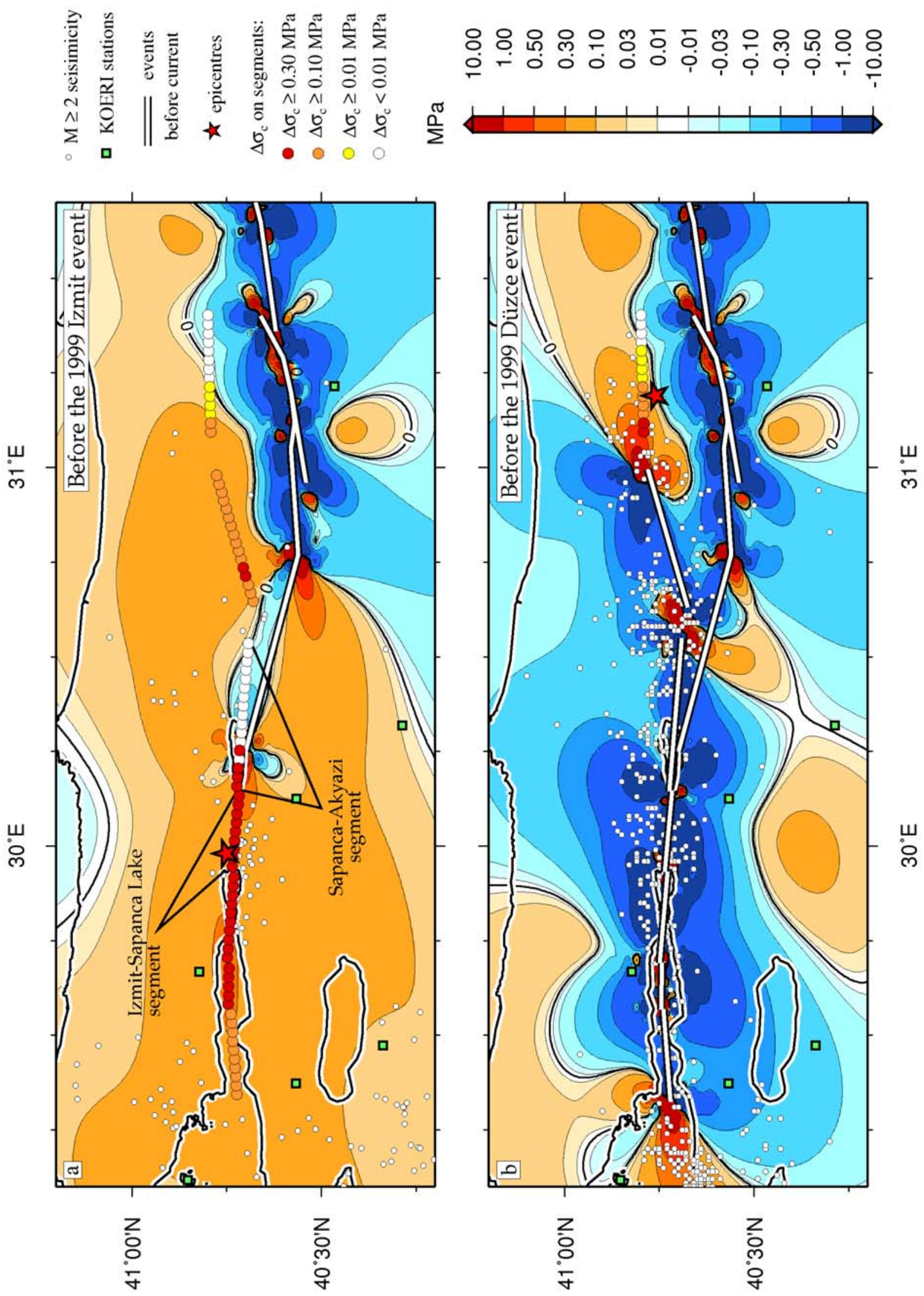

Figure 6 

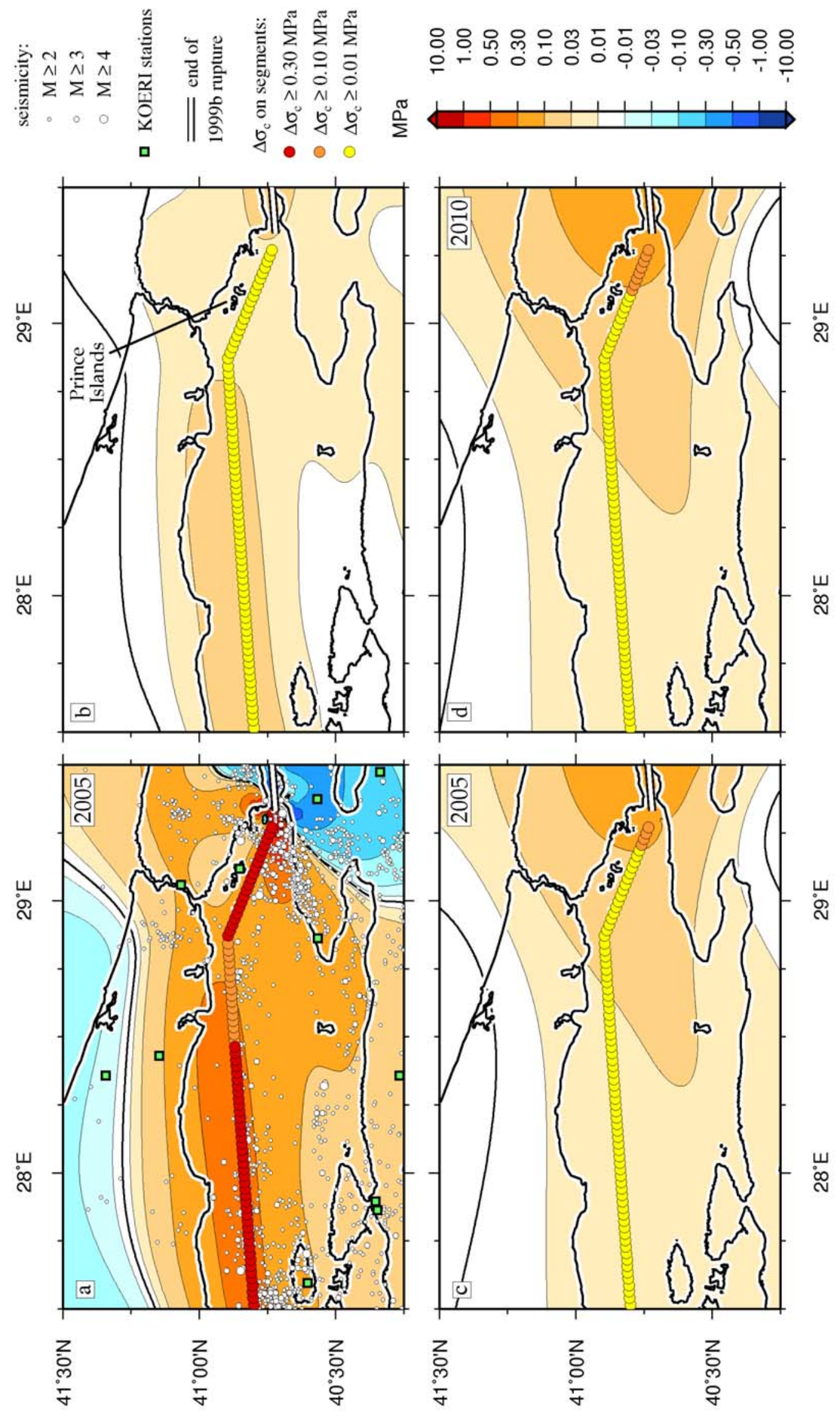

Figure 7 